\section{EPO, FACTOR VIII SHOCKERS}

NEW YORK-Two federal court rut ings came down in early March and staggered the biotech community. The U.S. Court of Appeals for the Federal Circuit (CAFC) upheld Amgen's (Thousand Oaks, CA) patent claims to erythropoietin (EPO). But at the same time, the appellate court struck down Genetics Institute's (GI, Cambridge, MA) patent to homogeneous EPO and compositions thereof-a shocking and totally unexpected result. Observers had expected a decision upholding a lower court ruling of mutual infringement, and were universally predicting a crosslicense between the two companies as the ultimate resolution of the longstanding dispute.

Then, less than a week later, the CAFC told Genentech (So. San Francisco, CA), the Scripps Clinic (La Jolla, CA), and Chiron (Emeryville, CA) that patent rights to factor VIII were still up for grabs. While news of the Amgen/GI ruling shook the financial markets, the factor VIII decision may signal the beginning of the end of broad biotech patent protection for purified natural proteins (socalled product-by-process claims).

Scripps scientists were the first to isolate and characterize the bloodclotting factor VIII:C. They used a process of chromatographic absorption of the factor VIII:C complex using monoclonal antibodies specific to factor VII related protein (factor VIII:RP), followed by separation of factor VIII:C. The Scripps patent describes the method of assay for clones producing antibodies to VIII:RP, their isolation, and preparation of monoclonal antibodies for use as the immunoabsorbant.

The CAFC ruling reverses summary judgment motions granted by the trial judge denying Scripps its patent, in part over a claim of inequitable conduct leveled by Genentech. Genentech had also successfully challenged Scripps' reasons for requesting a reissue of its patent to include broader claims.

Misconduct, however, depends on the intent of the parties to deceive or mislead, said the CAFC. And that calls for a showing of evidence. Similarly, it sent the issue of the breadth of the reissued patent claims down for determination at trial. Now, with an opportunity to argue the facts to support its patent claims, "Scripps has a real shot at it," says New York attorney S. Leslie Misrock of Pennie \& Edmonds. A win would deny Genentech, Chiron, and GI-another developer of factor VIII-a shot at marketing the product. that GI has produced "no evidence" to support its claim to EPO with a specific activity of at least 160,000 international units per absorbance unit (IU/AU) measured in vivo. Its patent was therefore struck down for lack of enablement.

According to the opinion, GI claimed it had purified urinary EPO (uEPO) to homogeneity by subjecting partially purified material to reverse phasehigh performance liquid chromatography (RP-HPLC). But the evidence before the magistrate at trial based on in vivo bioassays was limited to EPO with a specific activity of only $109,000 \mathrm{IU} / \mathrm{AU}$. GI had originally arrived at $160,000 \mathrm{IU} / \mathrm{AU}$ by calculation, before it had the ability to derive quantitative information. (The inventor had subjected $u E P O$ to RPHPLC and obtained an actual value of $83,000 \mathrm{IU} / \mathrm{AU}$. When he found that at least 50 percent of the area under the chromatograph curve was attributable to something other than uEPO, he doubled the value to arrive at a sepcific activity of at least 160,000 IU/AU.)

Such a "theoretical" procedure "does not establish that GI had a workable method for actually obtaining the pure material that it claimed," the CAFC said. Finding, as a matter of law, no credible evidence in support of the in vivo claim, it found that the holding the GI patent.

The decision guarantees Amgen and its marketing partner, Johnson \& Johnson (Rahway, NJ), a virtual monopoly to sell EPO in the U.S., where current fiscal-year sales of the drug are expected to reach $\$ \$ 350$ million. EPO was approved by the Food and Drug Administration to treat end-stage renal failure in June 1989. The FDA also approved it for use in combination with AZT to treat AIDS patients in early 1991.

The FDA may also eventually approve GI's EPO as an Orphan Drug if the company can show that its version possesses a clear clinical benefit over Amgen's. Absent a change in current international trade rules, GI partner Chugai (Tokyo) conceivably could manufacture EPO abroad and import it into the U.S. for sale. However, the so-called Boucher legislation, currently being debated in the U.S. Congress, would close this loophole in trade policy (see Bio/Tochnolog) 8:1239, Dec. ' 90 ). And GI said after the decision that "it is putting EPO in the U.S. behind it." -Mark Ratner
In the EPO ruling, the CAFC said trial court erred in its decision up-

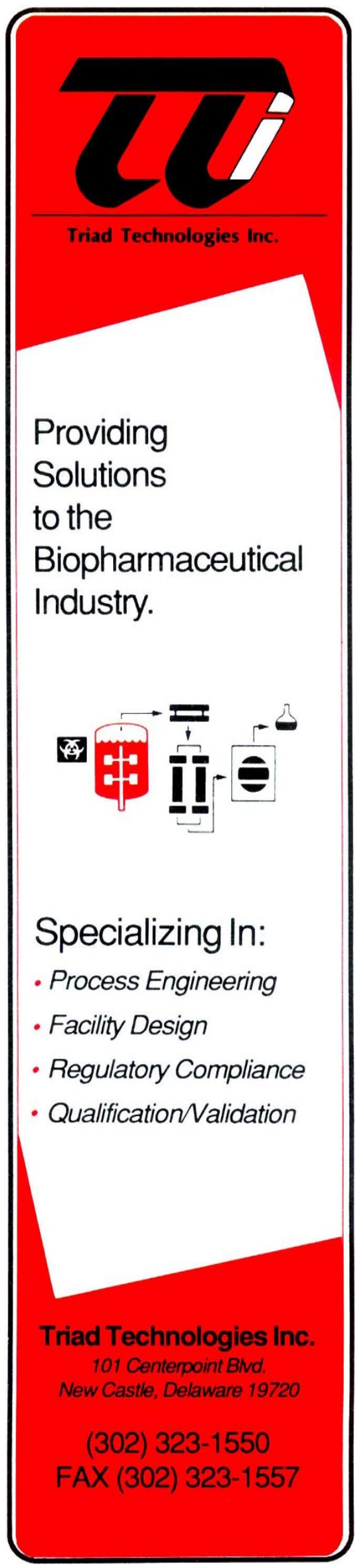

